\title{
Mid- and late Holocene dust deposition in western Europe: the Misten peat bog (Hautes Fagnes - Belgium)
}

\author{
M. Allan ${ }^{1}$, G. Le Roux ${ }^{2,3}$, N. Piotrowska ${ }^{4}$, J. Beghin ${ }^{5}$, E. Javaux ${ }^{5}$, M. Court-Picon ${ }^{5,6}$, N. Mattielli ${ }^{7}$, S. Verheyden ${ }^{6,8}$, \\ and N. Fagel ${ }^{1}$ \\ ${ }^{1}$ AGEs, Department of Geology, University of Liège, B18 Sart Tilman, Liège, Belgium \\ ${ }^{2}$ Université de Toulouse, INP, UPS, EcoLab (Laboratoire Ecologie Fonctionnelle et Environnement), ENSAT, \\ Avenue de l'Agrobiopole, 31326 Castanet Tolosan, France \\ ${ }^{3}$ CNRS, EcoLab, 31326 Castanet Tolosan, France \\ ${ }^{4}$ Department of Radioisotopes, GADAM Centre of Excellence, Institute of Physics, Silesian University of Technology, \\ Gliwice, Poland \\ ${ }^{5}$ Palaeobiogeology-Palaeobotany-Palaeopalynology, Department of Geology, University of Liège, Liège, Belgium \\ ${ }^{6}$ Royal Belgian Institute of Natural Sciences, Earth and Life History Division, Vautier street, 1000 Brussels, Belgium \\ ${ }^{7}$ G-Time, Dept. Earth and Environmental Sciences, Université Libre Bruxelles ULB, Bruxelles, Belgium \\ ${ }^{8}$ Scientific collaborator of the Vrije Universiteit Brussel, Brussel, Belgium \\ Correspondence to: M. Allan (mallan@doct.ulg.ac.be)
}

Received: 22 April 2013 - Published in Clim. Past Discuss.: 29 May 2013

Revised: 3 September 2013 - Accepted: 3 September 2013 - Published: 10 October 2013

\begin{abstract}
Dust deposition in southern Belgium is estimated from the geochemical signature of an ombrotrophic peatland. The rare earth elements (REE) and lithogenic elements concentrations, as well as $\mathrm{Nd}$ isotopes, were determined by HRICP-MS and MC-ICP-MS, respectively, along an $\sim 6 \mathrm{~m}$ peat section covering $5300 \mathrm{yr}$, from 2000 to $7300 \mathrm{cal} \mathrm{BP}$, dated by the ${ }^{14} \mathrm{C}$ method. Changes in REE concentration in the peat correlate with those of $\mathrm{Ti}, \mathrm{Al}, \mathrm{Sc}$ and $\mathrm{Zr}$ that are lithogenic conservative elements, suggesting that REE are immobile in the studied peat bogs and can be used as tracers of dust deposition. Peat humification and testate amoebae were used to evaluate hydroclimatic conditions. The range of dust deposition varied from 0.03 to $4.0 \mathrm{~g} \mathrm{~m}^{-2} \mathrm{yr}^{-1}$. The highest dust fluxes were observed from 2750 to $2550 \mathrm{cal} \mathrm{BP}$ and from 5150 to $4750 \mathrm{cal} \mathrm{BP}$, and correspond to cold periods. The $\varepsilon \mathrm{Nd}$ values show a large variability from -13 to -5 , identifying three major sources of dusts: local soils, distal volcanic and desert particles.
\end{abstract}

\section{Introduction}

Atmospheric dust is an important part of the global climate system, and plays an important role in the marine (Meskhidze et al., 2003) and terrestrial (Goudie and Middleton, 2006) biogeochemical cycles as a source for both major and trace nutrient elements. Reconstruction of dust composition and fluxes is crucial to help in understanding Holocene climate variability as well as ongoing biogeochemical cycles. In Europe, the Holocene was defined as a typical interglacial period with climate oscillations at various timescales, i.e. millennial, centennial and decadal.

Recently, the link between Holocene climate and atmospheric dust deposition has been intensively studied (e.g. Gabrielli et al., 2010; Kylander et al., 2013; Lambert et al., 2012; Marx et al., 2011; Sapkota et al., 2007; Thompson et al., 2003). Climate (dry and/or wet conditions) influences the intensity of the transport of air particles and their abundance (Goudie, 2001). Dust particles can be transported for thousands of kilometres before their deposition (Grousset et al., 2003). The principal sources of atmospheric dust are the world's deserts, and arid and semi-arid areas including northern and southern Africa, the Middle East and Asia, dry river 
banks, dewatered sea coast and Australia (Grousset and Biscaye, 2005). Local and regional anthropogenic sources may also influence the dust deposition (Tegen et al., 2004). Dust deposition depends on several factors, among which the dust concentration in the atmosphere, precipitation and vegetation cover (Lawrence and Neff, 2009).

Among other palaeoclimate archives, ombrotrophic peatlands (e.g. Le Roux et al., 2012; Kylander et al., 2007; Marx et al., 2005, 2009; Sapkota et al., 2007; Shotyk et al., 1998) and ice cores (e.g. Delmonte et al., 2004; Lambert et al., 2012; Thompson et al., 1995, 2000; Zdanowicz et al., 2000) are unique continental archives in which the dust content records exclusively the changes in atmospheric deposition of dusts during the last interglacial period. In recent decades, biological (e.g. plant macrofossils, peat humification, testate amoebae and pollen) and inorganic (e.g. particle size, mineralogy and chemistry of atmospheric mineral dust) proxies have been used in peat bogs to trace past changes in temperature and precipitation (e.g. Chambers et al., 2011; Roos-Barraclough et al., 2002; Shotyk et al., 2001; Väliranta et al., 2007). For example, the hydrological conditions strongly control the occurrence and relative abundance of different testate amoeba species on peatlands (Charman et al., 2000). By analysing testate amoebae community changes over a peat profile, it is possible to quantitatively and qualitatively reconstruct changing mire surface wetness (Booth et al., 2004; Lamentowicz et al., 2008; Sillasoo et al., 2007).

The different proxies may be partially interdependent but they are all controlled in a more or less direct way by climate. As each individual proxy has its own limitations and problems, it seems clear that a multi-proxy approach is necessary. In general, the mineralogy and the chemical and isotopic composition of the deposited dust should be similar to its source material (Aubert et al., 2006; Le Roux et al., 2012; Sapkota et al., 2006). Consequently, the chemistry of atmospheric dust particles trapped in the peat bogs can be used to distinguish between local, regional and hemispheric dust input (e.g. Krachler et al., 2003; Kamanov et al., 2009; Müller et al., 2007; Sapkota et al., 2006; Shotyk et al., 2002).

Rare earth elements (REE) are widely used to trace the different processes in cosmochemistry, igneous petrology and sedimentology because of their low solubility, transport occurring largely in the particulate phase in the atmosphere and their origin from natural sources (e.g. Taylor, 1972). Recently, REE have been used as tracers and reference elements in broad fields of atmospheric environmental studies (e.g. Le Roux et al., 2012), Nevertheless, to our knowledge, few studies including the present study have investigated the complete REE patterns in peat profiles to trace the dust sources (e.g. Aubert et al., 2006; Le Roux et al., 2012; Krachler et al., 2003). Radiogenic isotope signature of sediments is often used as provenance proxy as it is not affected by erosion and transport. In peatlands, $\mathrm{Nd}$ isotope data are scarce, only measured in a few sites (e.g. Etang de la Gruère in Switzerland, Le Roux et al., 2012). Neodymium isotopes may be used to discriminate the sources of dust in peats. By using a Swiss peat core, Le Roux et al. (2012) showed that the combination of dust flux and $\mathrm{Nd}$ isotope composition may successfully be applied to identify the sources of dust and to evidence climate forcing during the Holocene. Neodymium isotopes confirmed the importance of the Sahara as a dust source over western Europe (Le Roux et al., 2012).

In this study a continuous dust record for the period between 2000 and $7300 \mathrm{cal}$ BP is produced from a Belgian om$\mathrm{bro} /$ minerotrophic mire. The main aims are (1) to reconstruct changes in atmospheric dust deposition using $\mathrm{Al}, \mathrm{Ti}, \mathrm{Sc}, \mathrm{Zr}$ and REE elements; (2) to determine dust sources using REE content and $\mathrm{Nd}$ isotopes; (3) to investigate the relationship between dust flux and climatic variability during the midand late Holocene through a comparison of dust records from peat bogs with other "climatic indicator" proxies undertaken on the Misten peat bog (humification and testate amoebae); and (4) to compare dust records from peat bogs and ice cores in the Northern Hemisphere.

\section{Material and methods}

\subsection{Sampling and preparation}

In February 2008, a peat core (MIS-08-01b, $750 \mathrm{~cm}$ ) was collected from the Misten site in the Hautes-Fagnes Plateau, Belgium (Fig. 1). The top $100 \mathrm{~cm}$ was sampled by using a titanium Wardenaar corer (Wardenaar, 1987) from the University of Heidelberg. The lower peat was cored with a Belorussian corer (Belokopytov and Veresnevich, 1955). The upper $135 \mathrm{~cm}$, representing $2000 \mathrm{yr}$, are influenced by human activities. As such, we mainly focused our study on the prehistoric dust variability in the $135-750 \mathrm{~cm}$ depth interval that represents $\sim 5300 \mathrm{yr}$ (from 7300 to $2000 \mathrm{cal} \mathrm{BP}$ ). Core sub-samples of $1 \mathrm{~cm}$ thick slices were taken according to the protocol defined by Givelet et al. (2004). In Misten peat, $\mathrm{Ca} / \mathrm{Mg}$ ratios, $\mathrm{Sr}$ concentration and testate amoebae assemblages (unpublished data) were used to distinguish between the ombrotrophic and minerotrophic peat section (Payne, 2011; Shotyk, 1996; Shotyk et al., 2001). The peat is ombrotrophic (i.e. receiving inputs exclusively from the atmosphere) for the upper $6.8 \mathrm{~m}$ and minerotrophic for the lower interval (from 6.8 to $7.5 \mathrm{~m}$ ).

\subsection{Ash content and humification}

To identify the content of mineral matter defined as "ash content", 0.1 to $1 \mathrm{~g}$ of dried peat was taken from each subsample $(n=420)$ and heated to $550^{\circ} \mathrm{C}$ and kept at this temperature for a period of $6 \mathrm{~h}$ to remove all organic matter by combustion (Chambers et al., 2011). The humification degree was estimated by colorimetric method on peat alkaline extracts (Chambers et al., 2011) with a spectrophotometer for absorbance measurement at $540 \mathrm{~nm}$ available at the University of Liège (Belgium). 


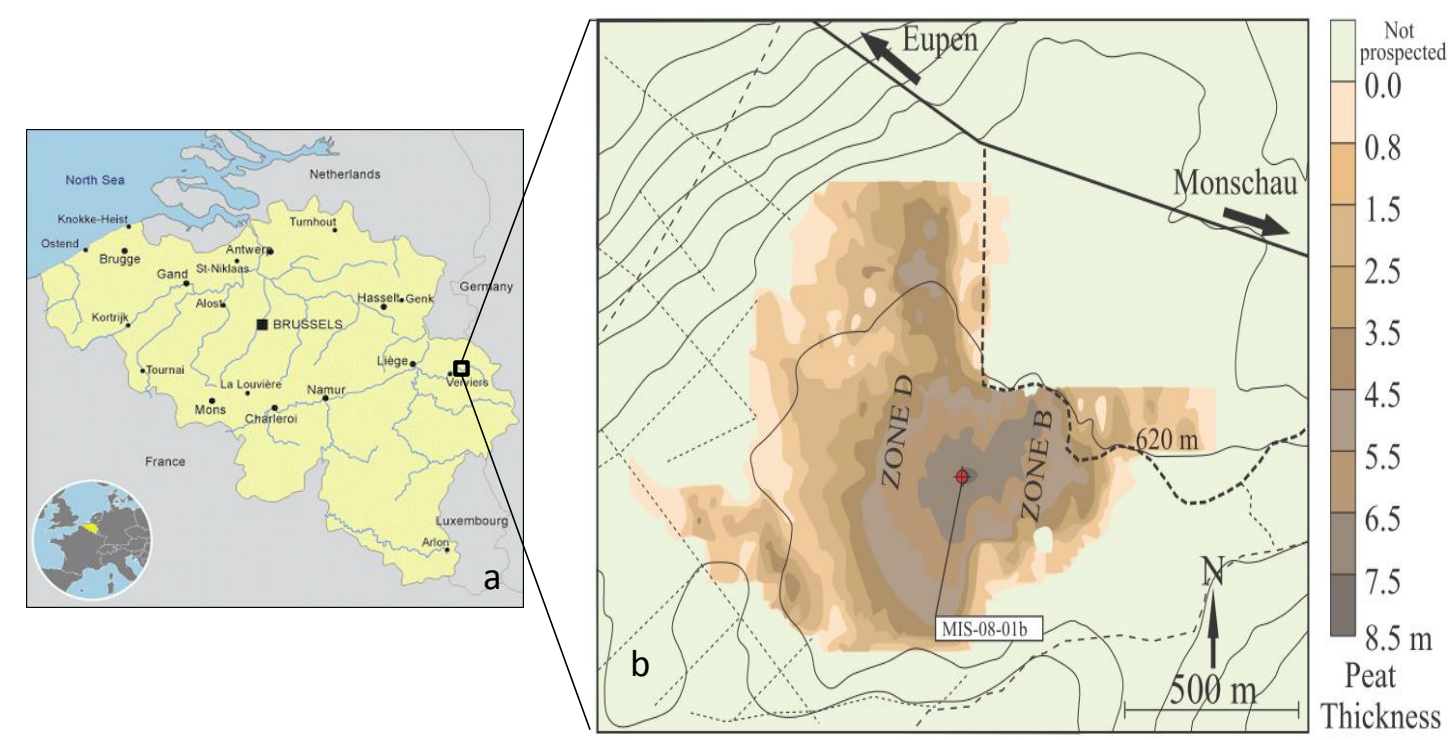

Fig. 1. (a) Location of the Misten peat bog in eastern Belgium, and (b) map of the Misten peat bog modified from De Vleeschouwer et al. (2007). The colouring indicates the peat thickness as deduced from surface radar prospection (Wastiaux and Schumacher, 2003). The red dot shows the location of the MIS-08-01b core.

\subsection{Chemical analyses}

Titanium (Ti), aluminium (Al), zirconium ( $\mathrm{Zr})$, scandium (Sc) and rare earth element (REE) concentrations of the peat were determined (about $200 \mathrm{mg}$ ) every $4 \mathrm{~cm}(n=170)$ by ICP-OES and HR-ICP-MS Thermo Element XR at the Observatoire Midi-Pyrénées in Toulouse (France) after complete dissolution of the $100 \mathrm{mg}$ of sample with a mixture of $\mathrm{HNO}_{3}$ - $\mathrm{HF}-\mathrm{H}_{2} \mathrm{O}_{2}$ in Savillex ${ }^{\circledR}$ beakers on a hot plate in a clean room (class 100). The standards (NIMT peat, ICHTJ CTA-OTL-1 oriental tobacco leaves, NIST tomato leaves 1573 and IAEA lichen 336) were used to assess the external analytical reproducibility.

Fifty-eight samples were prepared for $\mathrm{Nd}$ isotopes (Table 1). About $200 \mathrm{mg}$ of each sample was ashed at $550^{\circ} \mathrm{C}$ over a period of $6 \mathrm{~h}$ to remove all organic matter (Chambers et al., 2011). The dried organic-free samples were dissolved in a mixture of concentrated $\mathrm{HNO}_{3}$ and $\mathrm{HF}$ in a proportion of $1: 4$ heated at $125^{\circ} \mathrm{C}$ for $48 \mathrm{~h}$. After drying, $2 \mathrm{~mL}$ of $6 \mathrm{M} \mathrm{HCl}$ were added to ensure complete dissolution and that the solutions were evaporated. For separation of alkalis (e.g. $\mathrm{Ca}, \mathrm{Rb}, \mathrm{Sr}$ ) and REE, the samples were dissolved in $2 \mathrm{~mL}$ of $1 \mathrm{M} \mathrm{HCl}$ and passed on Bio-Rad columns filled with AG50W-X8 200 mesh resin (Ali and Srinivasan, 2011). Neodymium isotopes were isolated by passing the solution on quartz columns filled with HDEHP resin. The samples were dissolved a second time in $1.5 \mathrm{~mL} 0.05 \mathrm{M} \mathrm{HNO}_{3}$ before $\mathrm{Nd}$ isotopic measurement. The $\mathrm{Nd}$ isotopic ratios were measured by MC-ICP-MS (multi-collector inductively coupled plasma mass spectrometry, Nu Plasma) at G-Time laboratory (Universite Libre de Bruxelles). During the analysis, the $\mathrm{Nd}$ Rennes standard $\left({ }^{143} \mathrm{Nd} /{ }^{144} \mathrm{Nd}=0.511961 \pm 0.000008\right.$,
Chauvel and Blichert-Toft, 2001) was processed every two samples to correct for instrument drift. The mean values obtained for the Nd Rennes standard were stable during the measurement sessions: ${ }^{143} \mathrm{Nd} /{ }^{144} \mathrm{Nd}=0.511945 \pm 0.00002$ $(2 \sigma, \quad n \approx 150), \quad{ }^{145} \mathrm{Nd} /{ }^{144} \mathrm{Nd}=0.348404 \pm 0.000012$, ${ }^{146} \mathrm{Nd} /{ }^{144} \mathrm{Nd}=0.721598 \pm 0.000051$. Nd Rennes values are in agreement with the long-term laboratory value $\left[n=750,{ }^{143} \mathrm{Nd} /{ }^{144} \mathrm{Nd}=0.511946 \pm 0.00003\right]$. The $\mathrm{Nd}$ isotopes and epsilon $\mathrm{Nd}$ are given in Table 1. Epsilon neodymium $(\varepsilon \mathrm{Nd})$ was calculated according to DePaolo and Wasserburg (1976):

$\varepsilon \mathrm{Nd}=\left(\frac{(143 \mathrm{Nd} / 144 \mathrm{Nd})}{0.512638}-1\right) * 10000$,

where 0.512638 corresponds to the chondritic uniform reservoir (CHUR).

The ${ }^{143} \mathrm{Nd} /{ }^{144} \mathrm{Nd}$ ratios vary between 0.51184 and $0.51269\left(-13<\varepsilon \mathrm{Nd}<-5\right.$, Fig. 3), whereas ${ }^{147} \mathrm{Sm} /{ }^{144} \mathrm{Nd}$ ratios range from 0.1053 to 0.1398 (Table 1).

\subsection{Testate amoebae}

Testate amoebae were isolated from Misten peat by a wet sieving procedure (Booth et al., 2010; Beghin et al., 2013). One hundred tests were counted for each sample $(n=130)$ from the 7300 to $2000 \mathrm{cal}$ BP interval. The identification is done according to Charman et al. (2000) and Payne and Mitchell (2009). For a better visualisation of wet and dry periods, the testate amoebae were classified according to their affinity to wet or dry conditions (Charman et al., 2000). Slides were scanned at 10 to $40 \times$ magnification by using standard optical light microscopy. The relative abundance of 
Table 1. Sm-Nd analytical results of the samples from the Misten peat.

\begin{tabular}{|c|c|c|c|c|c|}
\hline sample & depth $(\mathrm{cm})$ & Age cal BP & ${ }^{143} \mathrm{Nd} /{ }^{144} \mathrm{Nd}$ & $2 \mathrm{se}$ & $\varepsilon \mathrm{Nd}$ \\
\hline 158 & 146 & 2137 & 0,5120522 & 0,00002 & $-11,4$ \\
\hline 142 & 170 & 2335 & 0,5120530 & 0,00002 & $-11,4$ \\
\hline 169 & 185 & 2404 & 0,5120180 & 0,00001 & $-12,1$ \\
\hline 172 & 189 & 2414 & 0,5120856 & 0,00001 & $-10,8$ \\
\hline 178 & 198 & 2494 & 0,5120364 & 0,00001 & $-11,7$ \\
\hline 182 & 204 & 2522 & 0,5121009 & 0,00001 & $-10,5$ \\
\hline 196 & 225 & 2632 & 0,5120130 & 0,00001 & $-12,2$ \\
\hline 203 & 230 & 2646 & 0,5119776 & 0,00001 & $-12,9$ \\
\hline 209 & 239 & 2687 & 0,5120455 & 0,00001 & $-11,6$ \\
\hline 221 & 257 & 2776 & 0,5120137 & 0,00001 & $-12,2$ \\
\hline 224 & 261 & 2814 & 0,5120627 & 0,00001 & $-11,2$ \\
\hline 240 & 280 & 3030 & 0,5120992 & 0,00001 & $-10,5$ \\
\hline 245 & 288 & 3109 & 0,5120382 & 0,00001 & $-11,7$ \\
\hline 248 & 293 & 3172 & 0,5121002 & 0,00001 & $-10,5$ \\
\hline 257 & 307 & 3292 & 0,5120936 & 0,00001 & $-10,6$ \\
\hline 269 & 321 & 3495 & 0,5121232 & 0,00001 & $-10,0$ \\
\hline 297 & 364 & 3884 & 0,5121395 & 0,00002 & $-9,7$ \\
\hline 311 & 380 & 3969 & 0,5120793 & 0,00001 & $-10,9$ \\
\hline 320 & 393 & 4056 & 0,5120760 & 0,00002 & $-11,0$ \\
\hline 329 & 407 & 4123 & 0,5120777 & 0,00001 & $-10,9$ \\
\hline 335 & 410 & 4148 & 0,5121256 & 0,00002 & $-10,0$ \\
\hline 352 & 435 & 4532 & 0,5121396 & 0,00004 & $-9,7$ \\
\hline 362 & 450 & 4619 & 0,5121375 & 0,00001 & $-9,8$ \\
\hline 365 & 451 & 4646 & 0,5120951 & 0,00001 & $-10,6$ \\
\hline 372 & 461 & 4753 & 0,5120659 & 0,00001 & $-11,2$ \\
\hline 377 & 468 & 4816 & 0,5121012 & 0,00003 & $-10,5$ \\
\hline 383 & 477 & 4856 & 0,5121426 & 0,00001 & $-9,7$ \\
\hline 392 & 491 & 4954 & 0,5121105 & 0,00001 & $-10,3$ \\
\hline 400 & 498 & 5051 & 0,5123538 & 0,00005 & $-5,5$ \\
\hline 404 & 504 & 5109 & 0,5121058 & 0,00001 & $-10,4$ \\
\hline 410 & 513 & 5209 & 0,5121088 & 0,00001 & $-10,3$ \\
\hline 413 & 518 & 5260 & 0,5120836 & 0,00001 & $-10,8$ \\
\hline 428 & 540 & 5516 & 0,5120002 & 0,00001 & $-12,4$ \\
\hline 437 & 549 & 5570 & 0,5121309 & 0,00001 & $-9,9$ \\
\hline 443 & 558 & 5686 & 0,5121284 & 0,00001 & $-9,9$ \\
\hline 449 & 567 & 5749 & 0,5121436 & 0,00001 & $-9,6$ \\
\hline 455 & 576 & 5807 & 0,5121391 & 0,00002 & $-9,7$ \\
\hline 461 & 585 & 5868 & 0,5122329 & 0,00002 & $-7,9$ \\
\hline 464 & 586 & 5879 & 0,5121023 & 0,00001 & $-10,5$ \\
\hline 476 & 603 & 5979 & 0,5121120 & 0,00001 & $-10,3$ \\
\hline 484 & 615 & 6082 & 0,5121573 & 0,00001 & $-9,4$ \\
\hline 494 & 630 & 6178 & 0,5121320 & 0,00002 & $-9,9$ \\
\hline 500 & 633 & 6221 & 0,5121447 & 0,00002 & $-9,6$ \\
\hline 509 & 647 & 6364 & 0,5121696 & 0,00001 & $-9,1$ \\
\hline 518 & 660 & 6522 & ,5121498 & 0,00001 & $-9,5$ \\
\hline 542 & 692 & 6786 & 0,5123354 & 0,00003 & $-5,9$ \\
\hline 548 & 701 & 6877 & 0,5123008 & 0,00003 & $-6,6$ \\
\hline 555 & 711 & 6948 & 0,5121199 & 0,00001 & $-10,1$ \\
\hline 569 & 712 & 6960 & 0,5121117 & 0,00002 & $-10,3$ \\
\hline 581 & 729 & 7053 & 0,5121198 & 0,00001 & $-10,1$ \\
\hline 590 & 743 & 7206 & 0,5122868 & 0,00001 & $-6,9$ \\
\hline \multicolumn{6}{|c|}{ duplicate } \\
\hline 169 & 185 & & 0,5120024 & 0,00192 & $-12,4$ \\
\hline 178 & 198 & & 0,5120511 & 0,00230 & $-11,4$ \\
\hline 196 & 225 & & 0,5120082 & 0,00169 & $-12,3$ \\
\hline
\end{tabular}

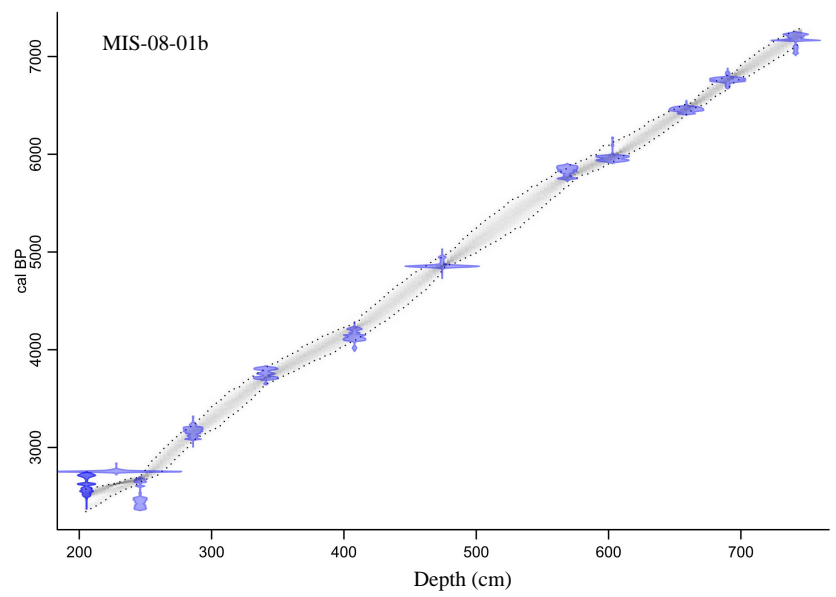

Fig. 2. Bacon age-depth model for the MIS-08-01b core. Grey scales indicate all likely age-depth models, and dotted lines indicate the $95 \%$ confidence ranges.

each species was calculated as a percentage of the total number of counted tests.

\subsection{Radiocarbon dating}

Radiocarbon ages were obtained on macrofossil samples (stems, branches or leaves of plant material) extracted under a binocular microscope. Samples were prepared at the GADAM Centre (Silesian University of Technology, Gliwice, Poland) according to the protocol described by Piotrowska et al. (2011) and Piotrowska (2013). Radiocarbon dates ( $n=15$, Table 2$)$ obtained by acceleration mass spectrometry (AMS) were processed using the "Bacon" software (Blaauw and Christen, 2011) to establish an age-depth model as well as an age range for each slice of peat (Fig. 2). The curve IntCal09 was used for calibration (Reimer et al., 2009). The age-depth model was calculated for $600 \mathrm{~cm}$ of the studied peat core. The accumulation rate was set as a gamma distribution with a mean of $10 \mathrm{yr} \mathrm{cm}^{-1}$. The accumulation variability was set with a beta distribution with strength of 4 and a mean of 0.7 .

\section{Results}

\subsection{Chronology of peat accumulation}

The ranges of calibrated radiocarbon ages of dated peat layers are presented in Table 2. The age-depth model (Fig. 2) covers the period from ca. $7300 \mathrm{BP}$ to $2000 \mathrm{BP}$. The age model reveals a relatively constant peat accumulation rate, with an average value of ca. $0.11 \mathrm{~mm} \mathrm{yr}^{-1}$. Consequently, the analysis of $1 \mathrm{~cm}$ thick samples represents ca. $9 \mathrm{yr}$ each, which limits the resolution of the dust flux reconstruction. 
Table 2. Results of ${ }^{14} \mathrm{C}$ dating for the MIS-08-01b peat core. Independently calibrated age ranges were obtained with the OxCal4 program (Bronk, 2009), and the modelled ages were obtained after "Bacon" calculations (Blaauw and Christen, 2011). In both cases the IntCal09 calibration curve was used (Reimer et al., 2009).

\begin{tabular}{lcrrr}
\hline Sample Name & Laboratory No & $\begin{array}{r}\text { Depth } \\
(\mathrm{cm})\end{array}$ & Age ${ }^{14} \mathrm{C}$ BP & $\begin{array}{r}\text { Modelled age } \\
\text { range BP } \\
\text { probability })\end{array}$ \\
\hline MIS-01/130 & GdA-1545 & 135,5 & $2085 \pm 30$ & $1990-2140$ \\
MIS-01/153 & GdA-1546 & 142,6 & $2185 \pm 35$ & $2115-2250$ \\
MIS-01/138 & GdA-1547 & 165,3 & $2240 \pm 35$ & $2150-2340$ \\
MIS-01/183 & GdA-1548 & 205,5 & $2530 \pm 35$ & $2490-2695$ \\
MIS-01/202 & GdA-2228 & 228 & $2635 \pm 20$ & $2740-2775$ \\
MIS-01/214 & GdA-2229 & 246 & $2440 \pm 20$ & $2400-2700$ \\
MIS-01/245 & GdA-2230 & 286,17 & $2980 \pm 25$ & $3075-3255$ \\
MIS-01/282 & GdA-2231 & 340,77 & $3470 \pm 20$ & $3650-3830$ \\
MIS-01/334 & GdA-2232 & 408,03 & $3770 \pm 30$ & $4000-4240$ \\
MIS-01/381 & GdA-2233 & 474,25 & $4300 \pm 30$ & $4830-4960$ \\
MIS-01/450 & GdA-2234 & 568,8 & $5050 \pm 20$ & $5740-5895$ \\
MIS-01/476 & GdA-2235 & 603 & $5210 \pm 30$ & $5910-6095$ \\
MIS-01/517 & GdA-2236 & 658,8 & $5680 \pm 20$ & $6410-6495$ \\
MIS-01/541 & GdA-2237 & 690 & $5940 \pm 20$ & $6680-6840$ \\
MIS-01/589 & GdA-2238 & 741,38 & $6235 \pm 20$ & $7025-7250$ \\
\hline
\end{tabular}

\subsection{Density, ash content and humification}

The density of the peat between 135 and $750 \mathrm{~cm}$ depth in the Misten core $(2000-7300 \mathrm{cal} \mathrm{BP})$ ranges between 0.01 and $0.12 \mathrm{~g} \mathrm{~cm}^{-3}$. The ash content varies between 0.1 and $2.4 \%$. The humification degree varies between 25 and $80 \%$ (Fig. 3). From 135 to $550 \mathrm{~cm}$ (2000-5570 cal BP, ombrotrophic section), the highest density corresponds to the more humified peat sections $(r=0.1)$. This similarity can be explained by plant breakdown during peat decomposition (Roos-Barraclough et al., 2002). In the lower peat section (below $680 \mathrm{~cm}$, minerotrophic peat), the ash content progressively increases towards the bottom of the core, in parallel with the density $(r=0.4)$. The intermediate peat section (from 550 to $680 \mathrm{~cm}, 5570-6675 \mathrm{cal} \mathrm{BP}$ ) is characterised by lower values of ash content and humification (Fig. 3).

\subsection{Elemental concentrations}

The conservative elements (Al, Sc, Ti, Zr) and REE concentration profiles in the Misten core are very similar (Fig. 4). We report La and Nd as light REE (LREE), Sm and Eu as medium REE (MREE) and $\mathrm{Yb}$ and Lu as heavy REE (HREE) (Fig. 4). The REE concentrations remain relatively low and constant between 550 and $680 \mathrm{~cm}$ (from 5570 to $6675 \mathrm{cal} \mathrm{BP}$ ). They increase three- to fivefold above $500 \mathrm{~cm}$ (5075 cal BP) and below $680 \mathrm{~cm}$ (Fig. 4). Correlation coefficients indicate individual REE vary in the same manner within the deposit with $r$ values $>0.95$.

\subsection{Dust flux}

According to Shotyk et al. (2002), the dust flux can be calculated using a conservative lithogenic element concentration $\left(\mu \mathrm{g} \mathrm{g}^{-1}\right)$ in the bulk peat, its occurrence in the upper continental crust (UCC, Taylor and McLennan, 1985), the density of the peat $\left(\mathrm{g} \mathrm{cm}^{-3}\right)$ and the peat accumulation rate $\left(\mathrm{cm} \mathrm{yr}^{-1}\right)$ :

Dust flux $\left(\mathrm{g} \mathrm{m}^{-2} \mathrm{yr}^{-1}\right)=\left([\text { element }]_{\text {sample }} /[\text { element }]_{\mathrm{UCC}}\right)$ *density*accumulation rate* 10000 .

The dust flux was calculated using $\mathrm{Ti}, \mathrm{Al}, \mathrm{Zr}$ and $\sum \mathrm{REE}$ (Fig. 5). The four dust flux profiles are very similar $(r>0.75$, $n=170$ ). This similarity is explained by the positive correlation between $\mathrm{Ti}, \mathrm{Al}, \mathrm{Zr}$ and $\sum \mathrm{REE}$ concentrations, and by the similar composition of a main part of the dust and the average UCC. The absolute values of the dust flux depend on the reference element used (e.g. Ti, Al, $\mathrm{Zr}$ ) to calculate it. The highest dust fluxes are observed from 210 to $250 \mathrm{~cm}$ depth (2-4.5 $\mathrm{g} \mathrm{m}^{-2} \mathrm{yr}^{-1}$, from 2750 to $\left.2550 \mathrm{cal} \mathrm{BP}\right)$ and from 510 to $460 \mathrm{~cm}$ depth $\left(1-2.4 \mathrm{~g} \mathrm{~m}^{-2} \mathrm{yr}^{-1}\right.$, from 5150 to $4750 \mathrm{cal} \mathrm{BP}$ ).

\subsection{Testate amoebae}

One hundred testate amoebae individuals were counted in the Misten peatland core. Five biozones (A to E) were defined by using CONISS (Grimm, 1987) according the testate amoebae assemblages (Table 3 and Fig. 6). The fluctuations were primarily driven by changes in the relative abundance of Amphitrema flavum, Difflugia pulex, Amphitrema wrightianum and Hyalosphenia subflava (Fig. 6). Zone A is 
Table 3. Descriptions of testate amoebae zones. Details on testate amoebae assemblage are given in Beghin et al. (2013).

\begin{tabular}{|c|c|c|c|c|}
\hline Zone & $\begin{array}{r}\text { Depth } \\
(\mathrm{cm})\end{array}$ & $\begin{array}{r}\text { Calendar } \\
\text { Age cal BP }\end{array}$ & Major taxa & Zone description \\
\hline $\mathrm{E}$ & $305-140$ & $3250-2085$ & $\begin{array}{l}\text { Hyalosphenia subflava } \\
\text { Amphitrema flavum and } \\
\text { Amphitrema wrightianum }\end{array}$ & $\begin{array}{l}\text { Hyalosphenia papilio and } \\
\text { Nebela militaris, Assulina musco- } \\
\text { rum, Assulina seminulum are vari- } \\
\text { ably abundant in this zone. Decrease } \\
\text { in Difflugia pulex }\end{array}$ \\
\hline $\mathrm{D}$ & $415-305$ & $4190-3250$ & $\begin{array}{l}\text { Difflugia pulex and } \\
\text { Amphitrema flavum }\end{array}$ & $\begin{array}{l}\text { Increase in Difflugia pulex, } \\
\text { Assulina muscorum, Assulina } \\
\text { seminulum. Appearance of Cyclopy- } \\
\text { xis } \\
\text { arcelloides, Hyalosphenia papilio } \\
\text { and Nebela militaris. }\end{array}$ \\
\hline $\mathrm{C}$ & $535-415$ & $5475-4190$ & Amphitrema flavum & $\begin{array}{l}\text { Decrease in Difflugia pulex. } \\
\text { Variable abundances of Assulina } \\
\text { muscorum, Assulina seminulum and } \\
\text { Difflugia pulex }\end{array}$ \\
\hline B & $660-535$ & $6520-5475$ & Difflugia pulex & $\begin{array}{l}\text { Decrease in Amphitrema flavum. In- } \\
\text { crease in Difflugia pulex. Variable } \\
\text { abundances of Assulina muscorum, } \\
\text { Assulina seminulum }\end{array}$ \\
\hline A & $750-660$ & $7300-6520$ & $\begin{array}{l}\text { Difflugia pulex and } \\
\text { Amphitrema flavum }\end{array}$ & Increase in Difflugia pristis \\
\hline
\end{tabular}

the minerotrophic part of the Misten peat bog. Zone B is dominated by Difflugia pulex and zone C by Amphitrema flavum; these zones display dry and wet conditions respectively. The taxonomic diversity is increasing in zone D. In zone E, the dominance of Amphitrema wrightianum and Hyalosphenia subflava is obvious; this could be due to higher amplitude fluctuations of the water table during the Late Holocene.

\section{Discussion}

\subsection{REE distribution pattern}

The REE variations in the Misten peat core, normalised to the mean upper continental crust values (UCC), are presented in three groups (Fig. 7) according to the peat core stratigraphy and characteristics (ombrotrophic, transition, minerotrophic).

The Misten peat bog has an overall relatively homogeneous REE $\mathrm{UCC}_{\mathrm{C}}$ composition (Fig. 7). The REE $\mathrm{UCC}_{\text {pattern }}$ of the three groups shows rather flat spectra with a slight MREE $_{\mathrm{UCC}}$ enrichment (Sm, Eu and Gd) with positive Eu anomalies. Both local (Belgian slate and shale) and distal (Saharan aerosol) sources of REE are characterised by a flat pattern (Fig. 7). However, The REE $\mathrm{UCC}_{\mathrm{C}}$ pattern in the third group (minerotrophic section) is higher than that shown by the two other groups, which may be explained by dominant local sources (Belgian slate and shale). The Eu anomaly clearly distinguishes minerotrophic against ombrotrophic peat layers (Fig. 4). In minerotrophic peat, there are thus processes affecting the REE distribution. Since the $\mathrm{Eu}$ anomaly is characteristic of plagioclase minerals (e.g. pan-African rocks, Cottin et al., 1998), this anomaly in the Misten bog can be explained by the contribution of weathered plagioclase material from local rocks. Indeed, the Stavelot Massif lithology, i.e. the geological bedrock, consists of metamorphic rocks, mainly quartzites and phyllites rich in quartz and plagioclase (Ferket et al., 1998).

\subsection{Dust source}

The parallel trends between REE profiles and conservative elements such as $\mathrm{Al}, \mathrm{Ti}$ and $\mathrm{Zr}\left(r_{\mathrm{Al}, \sum \mathrm{REE}}=0.8\right.$, $r_{\mathrm{Ti}, \sum \mathrm{REE}}=0.5, r_{\mathrm{Zr}, \sum \mathrm{REE}}=0.8$ ) (e.g. Aubert et al., 2006; Shotyk et al., 1998, 2001) (Fig. 4) attest that the REE are immobile in ombrotrophic peatland, and therefore their concentrations are controlled by atmospheric regional and/or local deposition (Aubert et al., 2006; Kylander et al., 2007; Shotyk et al., 1998, 2001). It also shows that REE are not affected by diagenetic processes. This observation confirms that the atmospheric REE pattern is preserved in the Misten bog. 


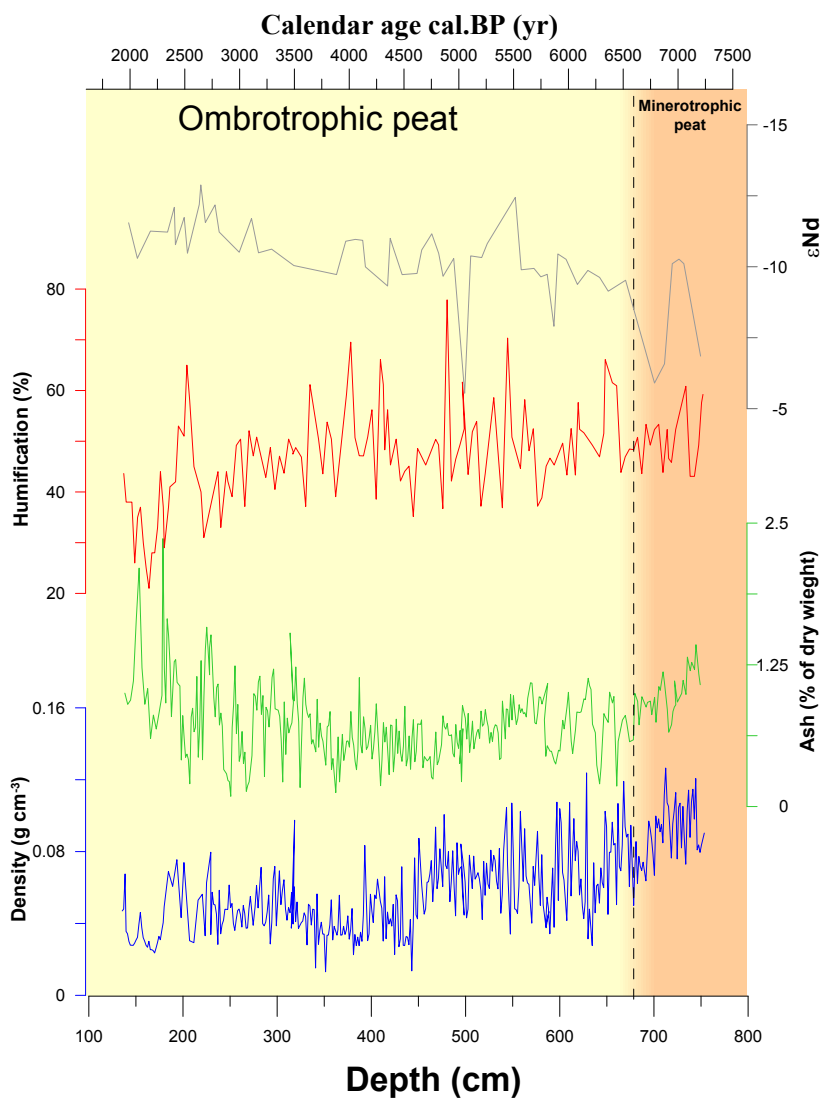

Fig. 3. Profiles of bulk density $\left(\mathrm{g} \mathrm{cm}^{-3}\right)$, ash content (\%), humification (\%) and $\varepsilon \mathrm{Nd}$. Light-brown areas correspond to the ombrotrophic peatland, and dark-brown bar to minerotrophic peat as defined by using $\mathrm{Ca} / \mathrm{Mg}$ ratios, $\mathrm{Sr}$ concentration and testate amoebae assemblages.

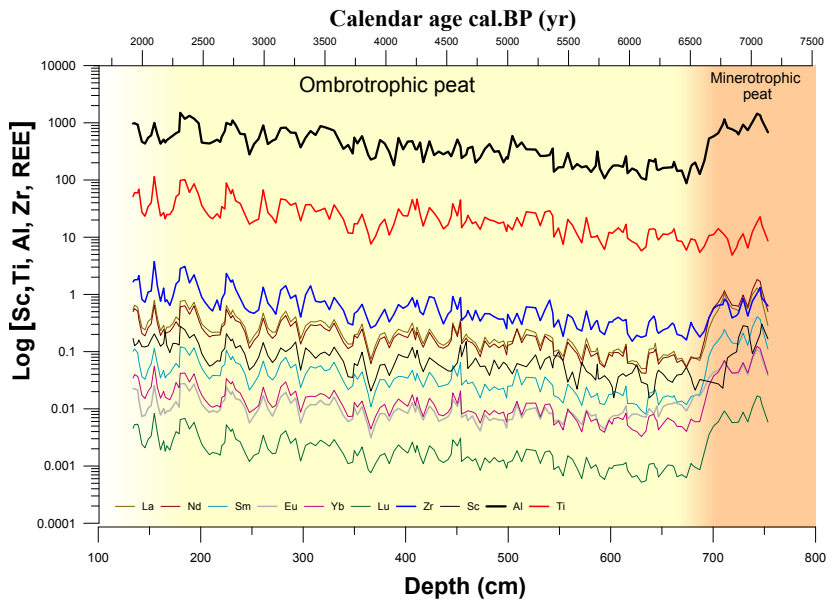

Fig. 4. Concentrations of $\mathrm{Ti}, \mathrm{Al}, \mathrm{Sc}, \mathrm{Zr}$ and $\mathrm{REE}$ for the MIS-08$01 \mathrm{~b}$ core. The yellow area corresponds to ombrotrophic peatland, the brown area to minerotrophic peat as defined by using $\mathrm{Ca} / \mathrm{Mg}$ ratios, $\mathrm{Sr}$ concentration and testate amoebae assemblages.

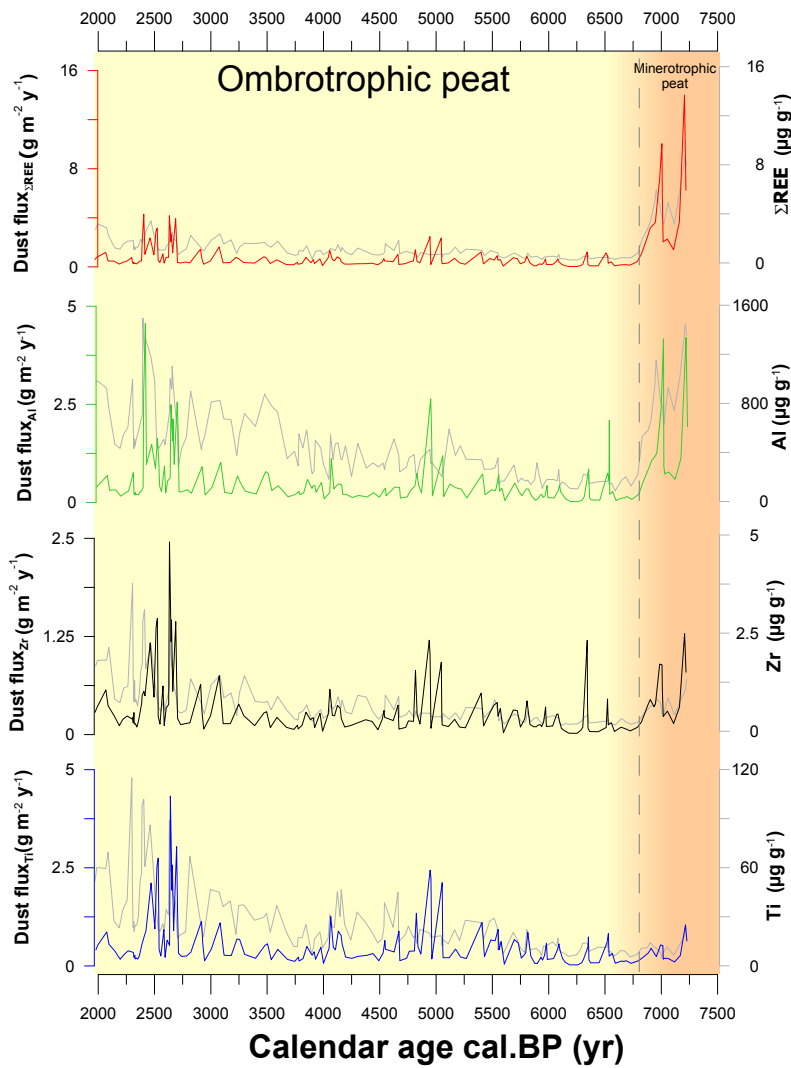

Fig. 5. Dust flux given in units of $\mathrm{g} \mathrm{m}^{-2} \mathrm{yr}^{-1}$ calculated for $\mathrm{Ti}$, $\mathrm{Zr}, \mathrm{Al}$ and $\sum \mathrm{REE}$. Grey lines correspond to $\mathrm{Ti}, \mathrm{Zr}, \mathrm{Al}$ and $\sum \mathrm{REE}$ concentrations. The yellow area corresponds to the ombrotrophic peatland, and the brown area to minerotrophic peat.

In general, dust, through its REE abundances and its $\mathrm{Nd}$ isotopic signature, keeps a fingerprint of its original sources (e.g. Abouchami et al. 1999; Akagi et al., 2002; Aubert et al., 2006; Krachler et al., 2003; Shotyk et al., 2001; Ylirukanen and Lehto, 1995). The origin of the Misten dust can be identified by the sample distribution as shown in diagrams such as $\varepsilon \mathrm{Nd}$ vs. $\mathrm{Sm} / \mathrm{Nd}$ and $\mathrm{La} / \mathrm{Sm}$ vs. $\mathrm{La} / \mathrm{Yb}$ (Fig. 8a, b). The $\varepsilon \mathrm{Nd}$ exhibits a large range, from -13 to -5 , emphasising the involvement of contrasting sources during the mid- to late Holocene. The diagram $\varepsilon$ Nd vs. ${ }^{147} \mathrm{Sm} /{ }^{144} \mathrm{Nd}$ (Fig. 8a) shows that the most of the Misten peat samples have an isotopic composition that overlaps that of Saharan aerosols $(\varepsilon \mathrm{Nd}$ varies between -15 and -11 , Abouchami et al., 1999) and that of European loess ( $\varepsilon \mathrm{Nd}$ between -12 and -8 , Gallet et al., 1998). This suggests a relatively constant input of both components throughout the mid- to late Holocene. However, the minerotrophic samples have $\varepsilon \mathrm{Nd}$ values (from -9 to -5 ) slightly less negative than those from the ombrotrophic peatland samples, suggesting an increased input from local sources relative to other inputs (e.g. shale, slate) between 7300 and $6650 \mathrm{cal} \mathrm{BP}$ (Fig. 8a). This is in agreement with the fact that minerotrophic peat could receive lateral inputs. 


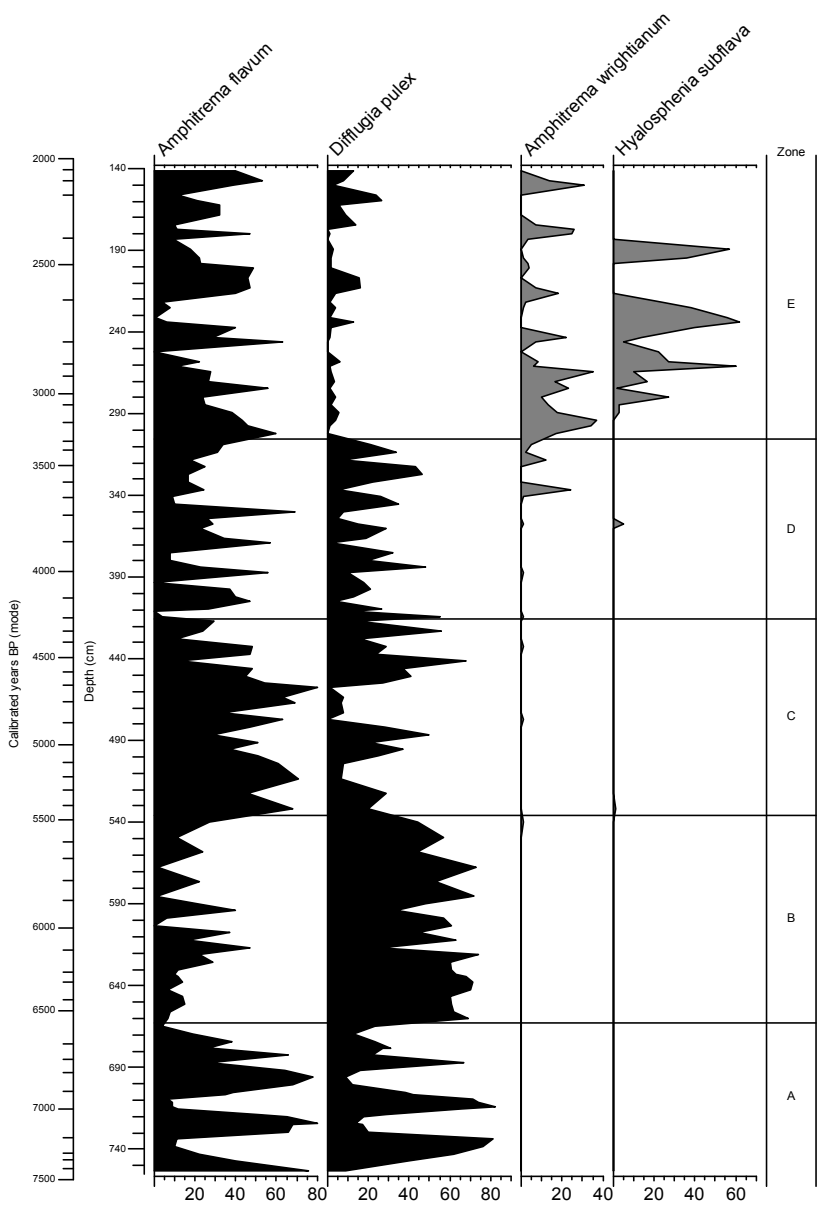

Fig. 6. Synthesised diagrams of dominant testate amoebae assemblages (\%) results from MIS-08-01b core.

The erosion of rocks present in the Cambrian and Silurian formations in Belgium (Linnemann et al., 2012), with specific $\varepsilon \mathrm{Nd}$ vs. ${ }^{147} \mathrm{Sm} /{ }^{144} \mathrm{Nd}$ signature, influences the $\mathrm{Nd}$ isotopic compositions of the peat, as showed by the less negative $\varepsilon \mathrm{Nd}$ values ( -8 to -5 , Table 1$)$. The abrupt changes in $\varepsilon \mathrm{Nd}$ at $\sim 6750 \mathrm{cal} \mathrm{BP}$ ( 2 points with $\varepsilon \mathrm{Nd}$ around -6 ) and $\sim 5050 \mathrm{cal} \mathrm{BP}(\varepsilon \mathrm{Nd}$ around -5.5$)$ can be due to mantlederived material such as long-range-transported volcanic material. The chronology of these points (6880 and $6785 \mathrm{cal} \mathrm{BP}$ ) corresponds to the well-known $\mu$ tephra named Lairg A and Lairg B respectively dated between 6913 (6974-6852 cal BP) and 6684 BP (6742-6627 cal BP) (Lawson et al., 2012). The chronology of the second point $(5150 \mathrm{cal} \mathrm{BP})$ does not correspond to that of a well-known tephra layer. The local source (Belgian metamorphic rocks, rich in plagioclase) and potential other sources (European loess, Saharan aerosol and Icelandic volcanism) are plotted in a $\mathrm{La} / \mathrm{Sm}$ vs. $\mathrm{La} / \mathrm{Yb}$ diagram (Fig. 8b). The distribution of the ombrotrophic peatland samples (2000-6650 cal BP) suggests a mixing between the local sources (quartzite and phyllade rocks rich in plagioclase) and the regional sources (European loess and Sa-

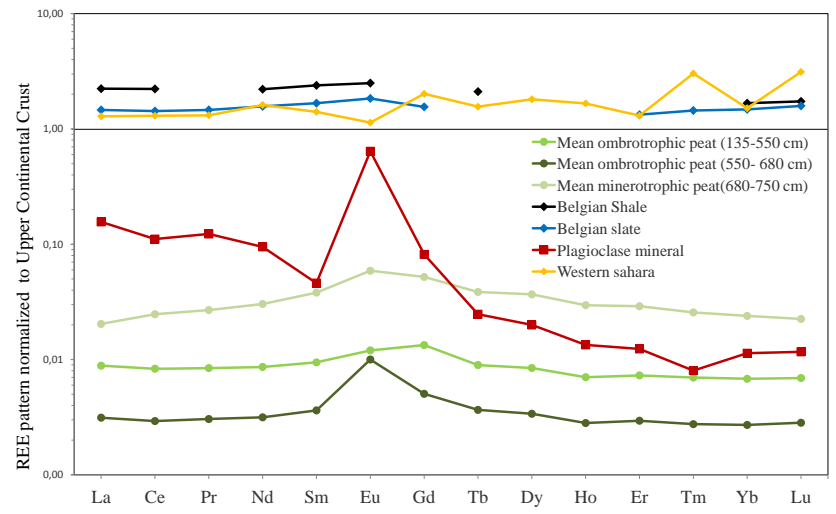

Fig. 7. REE average normalised to upper continental crust (UCC, Taylor and McLennan, 1985) and compared to those obtained from the western Sahara (Moreno et al., 2006), German snow profile (Black Forest, Aubert et al., 2006) and Belgian slate (Linnemann et al., 2012), Belgian shales (André et al., 1986), as well as to those obtained from plagioclase minerals collected in pan-African rocks (Laouni area, Cottin et al., 1998). The first group represents the

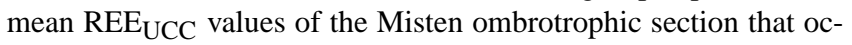
curs from 135 to $550 \mathrm{~cm}$ (between $5550 \mathrm{cal} \mathrm{BP}$ and $2000 \mathrm{cal} \mathrm{BP}$ ). The second group shows the transition zone from ombrotrophic to minerotrophic peat, from 550 to $680 \mathrm{~cm}$ (between 6650 and 5550 cal BP), and the third group represents the mean REE $_{U C C}$ values of the minerotrophic section occurs from 680 to $750 \mathrm{~cm}$ (between 7300 and 6650 cal BP).

haran aerosol). The minerotrophic peat samples (6700-7300 cal BP) are plotted between the $\mathrm{La} / \mathrm{Sm}$ and $\mathrm{La} / \mathrm{Yb}$ field defined for local sources (low in $\mathrm{La} / \mathrm{Sm}$ and $\mathrm{La} / \mathrm{Yb}$ ratios, Fig. 8b). This is in agreement with the findings based on the $\varepsilon \mathrm{Nd}$ (see above).

\subsection{Evolution of dust deposition during the mid- and late Holocene in the Misten peat core}

Dust deposition in the Misten peat record displays significant variability during the mid- and late Holocene, with two maxima observed from 5150 to $4750 \mathrm{cal} \mathrm{BP}$ and from 2750 to 2550 cal BP (Fig. 9). The highest rates of atmospheric dust deposition in Misten peat correspond to cold periods (Fig. 10), as defined in Wanner et al. (2011). Since the dust deposition seems to respond to regional climate change, colder periods should be linked to increased regional sources. We intend to check the climate imprint in the Misten record during mid- and late Holocene and especially for the two dust-enriched intervals. We integrate dust flux and $\mathrm{Nd}$ isotopes to track the climate influence in the Misten peat core. We identify the dominant natural atmospheric supplies by using $\mathrm{Nd}$ isotope composition, and interpret the changes of sources as local or global environmental changes. The $\varepsilon \mathrm{Nd}$ variability is further compared with the testate amoebae assemblages and the humification degree to evaluate the local relative humidity conditions. 

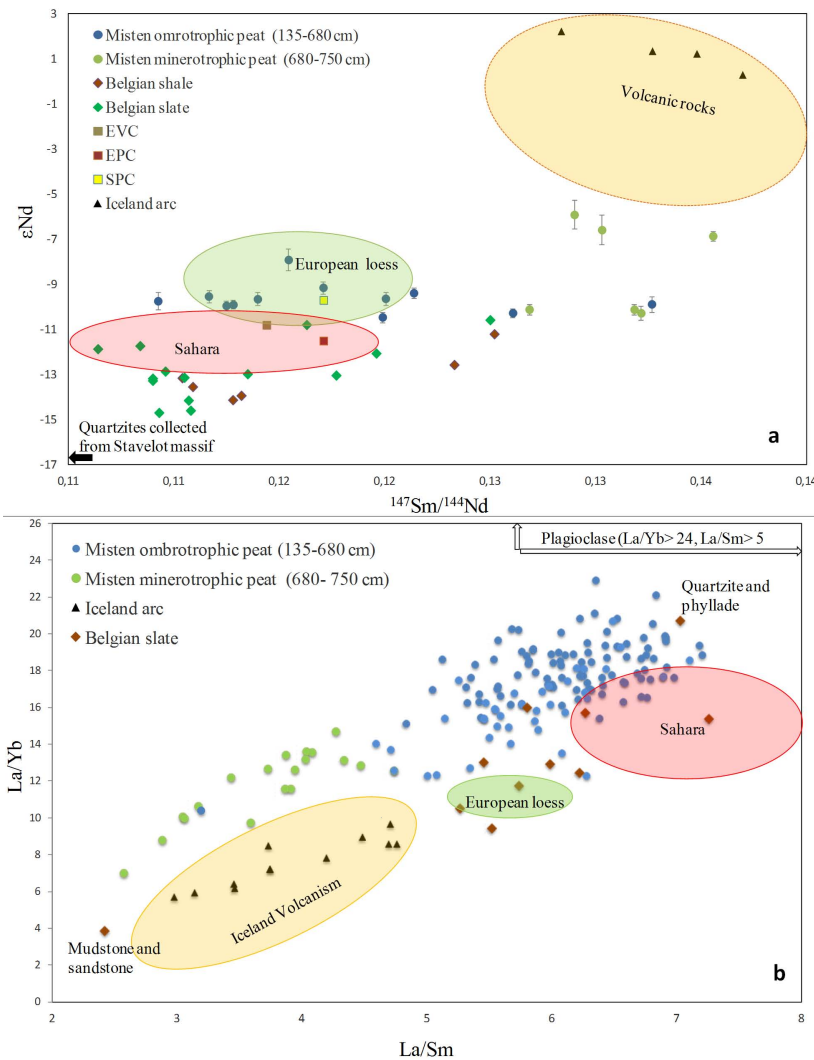

Fig. 8. (a) $\varepsilon \mathrm{Nd}$ vs. ${ }^{147} \mathrm{Sm} /{ }^{144} \mathrm{Nd}$ diagram for Misten peat samples. (b) $\mathrm{La} / \mathrm{Yb}$ vs. $\mathrm{La} / \mathrm{Sm}$ diagram for Misten peat samples. Belgian shale data from André et al. (1986), Belgian slate data recorded from Brabant Massif (Linnemann et al., 2012), Saharan aerosol data from Abouchami et al. (1999), Variscan crust (EVC), PanAfrican crust of northwestern Europe (EPC) and of the Scandinavian shield (SPC) from Fagel et al. (1999), Iceland arc from Handley et al. (2011) and European loess from Gallet el al. (1998).

1. The period between 7300 and $6000 \mathrm{cal} \mathrm{BP}$ corresponds to the warmest period of the Holocene in Greenland (Jonhsen et al., 2001). Peat growth at the Misten site starts at $\sim 7300 \mathrm{cal} \mathrm{BP}$, and becomes ombrotrophic from $6700 \mathrm{cal}$ BP. The minerotrophic section (7300$6700 \mathrm{cal} \mathrm{BP}$ ) is characterised by a low dust flux (averages of $0.3 \mathrm{~g} \mathrm{~m}^{-2} \mathrm{yr}^{-1}$, Fig. 9). This interval is characterised by wet local conditions attested by the high wet testate amoebae abundance (mean $\approx 49 \%$ ), and relatively low humification degree (44-52\%). Similarly, pollen data from the Hautes-Fagnes Plateau show that the studied area was at that time covered by dense mixed mesophilous woodlands (mainly oaks, associated with elms and lime trees) which were growing up to the edge of and even on peatlands (hazels, alders, ashes and birches), pointing to a wet and warm climate (Damblon, 1994).

From 6700 to 6000 cal BP, the dust flux and humification stayed relatively constant, with averages of

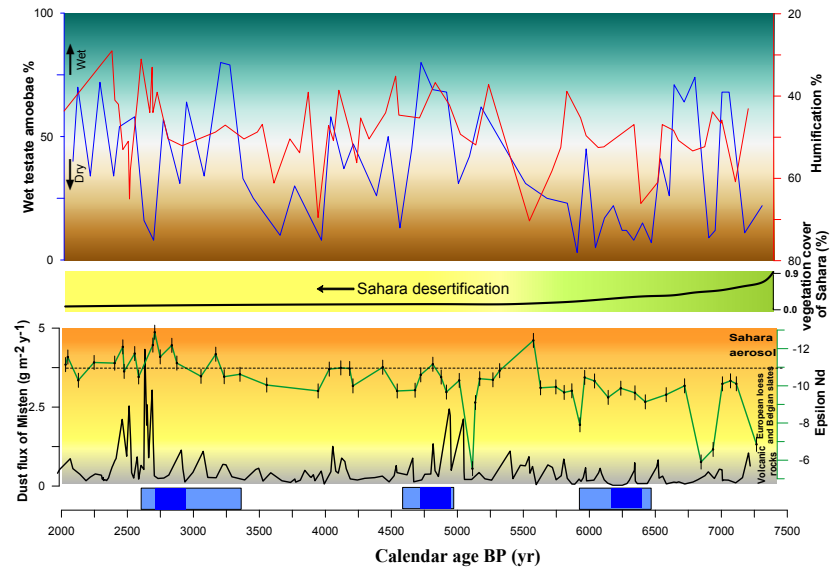

Fig. 9. Comparison of the Misten proxies (dust flux, $\varepsilon \mathrm{Nd}$, humification and testate amoebae). The testate amoebae were classified according to their affinity with wet conditions. The three darkblue bars show the cold events according to Wanner et al. (2011) and the three light-blue bars show the uncertainty in the length of cold events. The Saharan desertification model is from Claussen et al. (1999).

$0.3 \mathrm{~g} \mathrm{~m}^{-2} \mathrm{yr}^{-1}$ and $50 \%$ respectively (Fig. 9). The decrease in percentages of wet testate amoebae to $27 \%$ occurrence and the better representation of heathlands in pollen diagrams from the area (Damblon, 1994) show slightly drier local environments. For this interval there is no significant change in the dust flux intensity but the relatively dry conditions promote the erosion of local soils confirmed by the $\varepsilon \mathrm{Nd}$ values $(-10$ to -9$)$. Between 8000 and 5500 cal BP, Saharan aridification increased when Saharan vegetation cover decreased from 0.9 to $0 \%$ and the terrigenous material increased from 40 to $52 \%$ (Fig. 9, Bout-Roumazeilles et al., 2013; Claussen et al., 1999; DeMenocal et al., 2000)

2. The period from 6000 to $2800 \mathrm{cal} \mathrm{BP}$, the Misten dust flux increases compared to the mean value in the previous interval (from 7330 to $6000 \mathrm{cal} \mathrm{BP}$ ), with pronounced increases during two intervals, from 5150 to $4700 \mathrm{cal} \mathrm{BP}$ and from 2750 to $2550 \mathrm{cal} \mathrm{BP}$.

At 4700 cal BP, the dust flux reaches values of $2.4 \mathrm{~g} \mathrm{~m}^{-2} \mathrm{yr}^{-1}$. This interval is characterised by wet local conditions underlined by the high wet testate amoebae content (mean $\approx 60 \%$ ) and the low humification degree (mean $\approx 46 \%$ ), indicating wet conditions. The humid conditions are in agreement with the vegetal cover changes of the Hautes-Fagnes Plateau deduced from palynology (increase in oak and beech species, local increase in hygrophilous and aquatic pollen taxa, Damblon, 1994) and with a positive humidity anomaly at the scale of the Northern Hemisphere between 4800 and $4600 \mathrm{cal} \mathrm{BP}$ as described in 


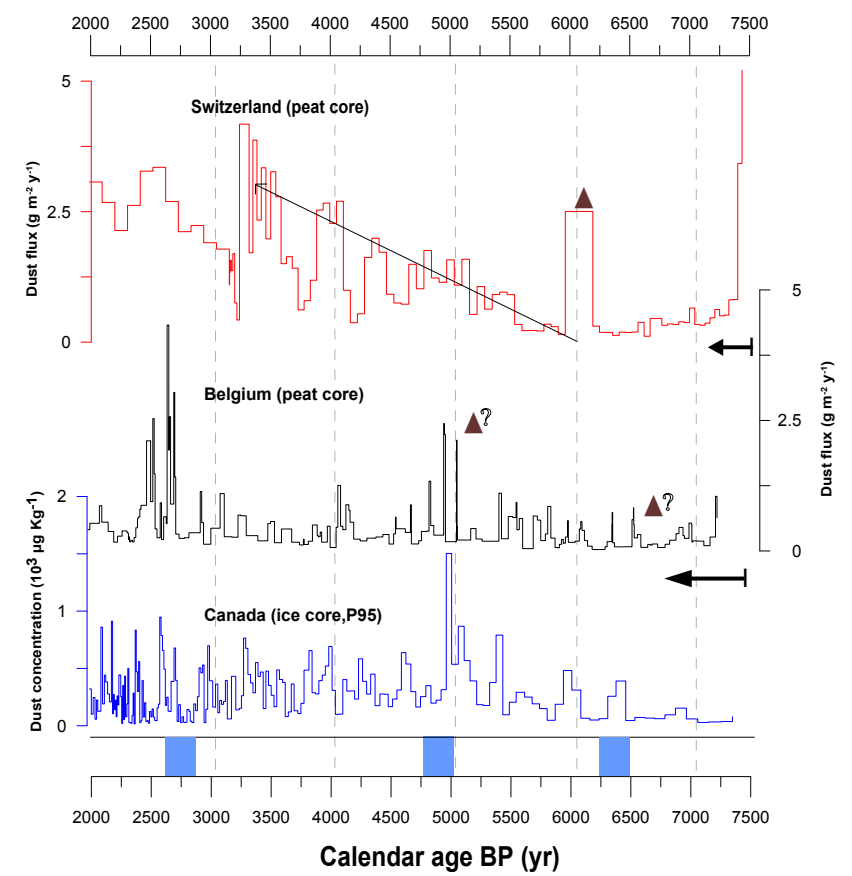

Fig. 10. Comparison of the dust flux measured in the Misten bog (black line, this study) with the dust flux $\left(\mathrm{g} \mathrm{m}^{-2} \mathrm{yr}^{-1}\right)$ obtained from a Swiss peat core (green line, Le Roux et al., 2012) and with the dust concentration $\left(10^{3} \mu \mathrm{g} \mathrm{kg}^{-1}\right)$ measured in a Canadian ice core from Zdanowicz et al. (2000). The three dark-blue bars show the cold events described in Wanner et al. (2011). Brown triangles represent the volcanic events. Black arrows underline the minerotrophic peat sections.

Wanner et al. (2011). The higher flux values indicate more distal supplies $(\varepsilon \mathrm{Nd}$ values vary from -9.7 to -11.2 , except for one sample with $\varepsilon \mathrm{Nd}=-5$ suggesting a volcanic or local source), the local erosion being reduced by the wetter soil conditions, as underlined by a decrease of the humification degree plus a change in the wet testate amoebae content.

Between 4500 and 4000 cal BP, the dust flux increases to a value $>1 \mathrm{~g} \mathrm{~m}^{-2} \mathrm{yr}^{-1}$ at 4100 cal BP (Fig. 9). The general decrease of wet testate amoebae to $20 \%$ occurrence and the increase of the humification degree to $52 \%$ both indicate a drier local environment. In this interval $\varepsilon \mathrm{Nd}$ varies between -9 and -11 , reflecting local and regional sources. The increase in dust flux may relate to the important local erosion. By using Spanish speleothems, Martín-Chivelet et al. (2011) show that the interval from 4000 to $2950 \mathrm{cal} \mathrm{BP}$ is a warm period punctuated by cold events. The glaciers retreat in Europe from 4200 to 3800 cal BP (Mayewski et al., 2004), and the lake-level minima (Magny, 2004) confirm a dry interval.

Between 3200 and $2500 \mathrm{cal} \mathrm{BP}$, the dust flux increases and reaches the maximum core value $\left(4.3 \mathrm{~g} \mathrm{~m}^{-2} \mathrm{yr}^{-1}\right)$.
The humification degree decreases to $42 \%$ and wet testate amoebae occurrence declines to $\sim 20 \%$ (Fig. 9). The regional pollen data indicate a strong expansion of beech forests at the expense of the mixed oak woodlands, whereas alders and birches developed again near and on wetlands. These changes point not only to a climatic deterioration with cold and dry conditions but also to soil degradation (Damblon, 1994), and coincide with a cold event identified by Wanner et al. (2011) between 3300 and $2500 \mathrm{cal} \mathrm{BP}$. The $\varepsilon \mathrm{Nd}$ displays highly negative values, reflecting an increased supply from Saharan sources. According to the pollen, anthropogenic activities appeared in the Hautes-Fagnes Plateau around 3500 BP, but they remained low and did not seem to have affected local ecological evolution (Damblon, 1994).

3. Between 2550 and 2000 cal BP the dust flux displays high values (averages of $0.6 \mathrm{~g} \mathrm{~m}^{-2} \mathrm{yr}^{-1}$ ). At the same time, a low humification degree $(35 \%)$ is consistent with cold and dry conditions and an intensification of human impact is recorded in the pollen diagrams of the Hautes-Fagnes area (Damblon, 1994). This period is therefore most probably characterised by the influence of human activities related to land use change (regional erosion due to forest clearing and soil cultivation activities).

\subsection{Comparison of dust deposition records from peat bogs and ice cores}

We compare the Misten dust record with another European peat bog in Switzerland (Le Roux et al., 2012) and with an ice core collected from Canada (Zdanowicz et al., 2000) (Fig. 10). Both dust depositions, recorded in the Misten peat and in the Canadian ice core, reach their maxima from 5500 to $4800 \mathrm{cal} \mathrm{BP}$ and from 2700 to $2200 \mathrm{cal} \mathrm{BP}$ (Fig. 10). During the interval spanning the cold stages defined by Wanner et al. (2011), the dust fluxes are 2 to 20 times higher than the sedimentary background. These two archives (peat and ice cores) show, however, significant differences in the timing and magnitude of reconstructed dust.

The dust flux record reconstructed from the Misten peat core is comparable to results obtained from the Swiss peat bogs although resolution of dust measurement was different. In the latter, Le Roux et al. (2012) showed that the dust flux in the ombrotrophic peatland at Etang de la Gruère varies between 0.1 and $5 \mathrm{~g} \mathrm{~m}^{-2} \mathrm{yr}^{-1}$ from 8000 to $2000 \mathrm{cal} \mathrm{BP}$. The dust flux measured in Misten peat varies within a similar range, from 0.1 to $4.5 \mathrm{~g} \mathrm{~m}^{-2} \mathrm{yr}^{-1}$ from 7300 to 2000 cal BP (Fig. 10). The dust fluxes in both peat cores were at a minimum $\left(<1 \mathrm{~g} \mathrm{~m}^{-2} \mathrm{yr}^{-1}\right)$ from 7500 to $5500 \mathrm{cal} \mathrm{BP}$, except at 6000 cal BP, when dust fluxes measured in the Swiss peat reached $2.5 \mathrm{~g} \mathrm{~m}^{-2} \mathrm{yr}^{-1}$, corresponding to an unknown event. At Etang de la Gruère the dust deposition increased 
significantly between 5500 and $3200 \mathrm{cal} \mathrm{BP}$ and the maximum occurred at 3300 cal BP, as shown in Fig. 10 (Le Roux et al., 2012). These changes were linked to forest clearing and the beginning of plant cultivation (Shotyk et al., 2002). The significant increase in dust flux in the Swiss peat after $6000 \mathrm{calBP}$ is in agreement with the timing of Saharan expansion, between 8000 and $5500 \mathrm{cal} \mathrm{BP}$, as supported by palaeoenvironmental data from the West African Atlantic coast (Claussen et al., 1999; deMenocal et al., 2000). During that period, Saharan aridification increased when Saharan vegetation cover decreased from 0.9 to $0 \%$ and the terrigenous material increased from 40 to $52 \%$ (Fig. 9).

In the Misten peat, dust fluxes oscillate between 5500 and $3200 \mathrm{cal} \mathrm{BP}$ and reaches a maximum $\left(2.5 \mathrm{~g} \mathrm{~m}^{-2} \mathrm{yr}^{-1}\right)$ at $5000 \mathrm{calBP}$. Its timing corresponds to a cold event described by Wanner et al. (2011). From 2500 to 2000 cal BP, dust flux measured in Swiss peat core (Le Roux et al., 2012) ranges between 2 and $3 \mathrm{~g} \mathrm{~m}^{-2} \mathrm{yr}^{-1}$, up to $5 \times$ higher than that measured in the Misten peat core (dust flux ranges from 0.2 to $0.8 \mathrm{~g} \mathrm{~m}^{-2} \mathrm{yr}^{-1}$, Fig. 10). This difference in dust flux would be an indication for increased human activities (open pasture, agriculture and mining activities). Anthropogenic effects explaining the maximum in the Swiss peat bog do not seem to have an important effect during this period in the Misten core. Sjogren (2006) showed that the open pastures started around Etang de la Gruère bog during the first centuries BC, as shown by peat studies, but only started around Misten peatland before $850 \mathrm{cal}$ BP (De Vleeschouwer et al., 2012).

Our study, by using dust deposition and $\mathrm{Nd}$ isotopes, shows the relative importance of the Sahara as a dust supplier over Belgium on a long-term basis, including during abrupt events such as from 5150 to $4750 \mathrm{cal} \mathrm{BP}$ and from 2750 to 2550 cal BP.

\section{Conclusions}

Elemental concentrations and $\mathrm{Nd}$ isotopes analysed in an $\sim 6 \mathrm{~m}$ long peat core collected from the Hautes-Fagnes Plateau (southern Belgium) allow for identification of dust sources. Humification and testate amoebae have been used to reconstruct dry/wet climatic conditions during the midand late Holocene. The clear correlation between REE and conservative element concentrations ( $\mathrm{Ti}, \mathrm{Al}, \mathrm{Zr}$ ) in the Misten peat core confirm that the atmospheric REE input is preserved in the peat bog. The general agreement between the dust flux and the palaeo-hydrological proxies (humification and testate amoebae) confirms the increase in dust deposition during colder periods within the Holocene. To identify the dust sources, we compared the $\mathrm{Nd}$ isotopic ratios and REE ratios of the Misten peat with those of different potential local and regional sources. The $\varepsilon \mathrm{Nd}$ range from -13 to -5 , reflecting a diversity of sources during the midand late Holocene, with large supplies from distal (Saha- ran) and regional (European loess) particles, local aerosols and distal volcanic particles from Iceland. After $6000 \mathrm{cal} \mathrm{BP}$, sources were restricted to Saharan and European aerosols, corresponding to a change to locally wetter conditions. The average dust flux of $0.5 \mathrm{~g} \mathrm{~m}^{-2} \mathrm{yr}^{-1}$ reached values as high as $2 \mathrm{~g} \mathrm{~m}^{-2} \mathrm{yr}^{-1}$ between 5150 and $4750 \mathrm{cal} \mathrm{BP}$ and around 2750 cal BP. Comparison between the Misten record and a peat record from Switzerland shows that anthropogenic perturbation of the dust cycle occurred earlier in Switzerland than in the more hostile environment of the Plateau des Hautes-Fagnes, where the Misten bog is located.

Acknowledgements. This study was funded by the Walloon Region and the FNRS. M. Allan received funding through a $\mathrm{PhD}$ grant from the government of Syria. We acknowledge the service ICP-MS of the Observatoire Midi-Pyrénées for the analytical facilities.

Edited by: Y. Godderis

\section{References}

Abouchami, W., Galer, S. J. G., and Koschinsky A.: Pb and Nd isotopes in NE Atlantic Fe-Mn crusts: Proxies for trace metal paleosources and paleocean circulation, Geochim. Cosmochim. Acta., 63, 1489-1505, 1999.

Akagi, T., Feng-Fu, F., Yabuki, S.: Absence of Ce anomaly in the REE patterns of peat moss and peat grass in the Ozegahara peatland, Geochem. J., 36, 113-118, 2002.

Ali, A. and Srinivasan, G.: Precise thermal ionization mass spectrometric measurements of $142 \mathrm{Nd} / 144 \mathrm{Nd}$ and ${ }^{143} \mathrm{Nd} /{ }^{144} \mathrm{Nd}$ isotopic ratios of $\mathrm{Nd}$ separated from geological standards by chromatographic methods, Int. J. Mass. Spectrom., 299, 27-34, 2011.

André, L., Deutsch, S., and Hertogen, J.: Trace-element and Nd isotopes in shales as indexes of provenance and crustal growth: The early Paleozoic from the Brabant Massif (Belgium), Chem. Geol., 57, 101-115, 1986.

Aubert, D., Le Roux, G., Krachler., M., Cheburkin, A., Kober., B., Shotyk., W., and Stille., P.: Origin and fluxes of atmospheric REE entering an ombrotrophic peat bog in Black Forest (SW Germany): Evidence from snow, lichens and mosses, Geochim. Cosmochim. Acta, 70, 2815-2826, 2006.

Beghin, J., Salpeteur, T., Charman, D., Lamentowicz, M., Gerrienne, P., Streel, M., Court-Picon, M., Allan, M., Fagel, N., and Javaux E.: Surface wetness reconstruction using testate amoebae analysis of the mid to late Holocene Misten peat bog (HautesFagnes, eastern Belgium), in preparation, 2013.

Belokopytov, I. E. and Veresnevich, V. V.: Giktorf's peat borers, Torfânaâ promyslennost', 8, 9-10, 1955.

Blaauw, M. and Christen, J. A.: Flexible paleoclimate age-depth models using an autoregressive gamma process, Bayesian Analysis, 6, 457-474, 2011.

Blaauw, M., van Geel, B., and van der Plicht, J.: Solar forcing of climate change during the mid-Holocene: indications from raised bogs in The Netherlands, The Holocene, 14, 34-44, 2004.

Booth, R. K., Jackson, S. T., and Gray, C. E. D.: Paleoecology and high-resolution paleohydrology of a kettle peatland in upper Michigan, Quaternary Res., 61, 1-13, 2004. 
Booth, R. K., Lamentowicz, M., and Charman, D. J.: Preparation and analysis of testate amoebae in peatland palaeoenvironmental studies, Mires and Peat, 7, 1-7, 2010.

Bout-Roumazeilles, V., Combourieu-Nebout, N., Desprat, S., Siani, G., Turon, J.-L., and Essallami, L.: Tracking atmospheric and riverine terrigenous supplies variability during the last glacial and the Holocene in central Mediterranean, Clim. Past, 9, 10651087, doi:10.5194/cp-9-1065-2013, 2013.

Bronk, R. C.: Bayesian analysis of radiocarbon dates, Radiocarbon, 51, 337-360, 2009.

Chambers, F. M., Booth, R. K., De Vleeschouwer, F., Lamentowicz, M., Le Roux, G., Mauquoy, D., Nichols, J. E. and van Geel, B.: Development and refinement of proxyclimate indicators from peats, Quaternary Int.,268, 21-33, doi:10.1016/j.quaint.2011.04.039, 2011.

Charman, D. J., Hendon, D., and Woodland, W.: The identification of peatland testate amoebae. Quaternary Research Association Technical Guide no.9, London, UK, 2000.

Chauvel, C. and Blichert-Toft, J.: A hafnium isotope and trace element perspective on melting of the depleted mantle, Earth Planet. Sci. Lett., 190, 137-151, 2001.

Claussen, M., Kubatzki, C., Brovkin, V., Ganopolski, A., Hoelzmann, P., and Pachur, H. J.: Simulation of an abrupt change in Saharan vegetation in the mid-Holocene, Geophys. Res. Lett., 26, 2037-2040, doi:10.1029/1999GL900494, 1999.

Cottin, J. Y., Lorand, J. P., Agrinier, P., Bodinier, J. L., and Lieegeois, J. P.: Isotopic $(\mathrm{O}, \mathrm{Sr}, \mathrm{Nd})$ and trace element geochemistry of the Laouni layered intrusions (Pan-African belt, Hoggar, Algeria): evidence for post-collisional tholeiitic magmas variably contaminated by continental crust, Lithos., 45, 197-222, 1998.

Damblon, F.: Les dépôts tourbeux et l'histoire de la végétation sur le plateau des Hautes-Fagnes (Belgique), Annales de la Société géologique de Belgique, 117, 259-276, 1994.

Davis, B. A. S. and Brewer, S.: Orbital forcing and the role of the Latitudinal Temperature/Isolation Gradient, Clim. Dynam., 32, 143-165, 2009.

Davis, B. A. S., Brewer, S., Stevenson, A. C., Guiot, J., and Data contributors: The temperature of Europe during the Holocene reconstructed from pollen data, Quaternary Sci. Rev., 22, 17011716, 2003.

DeMenocal, P., Ortiz, J., Guilderson, T., Adkins, J., Sarnthein, M., Baker, L., and Yarusinsky, M.: Abrupt onset and termination of the African Humid Period: Rapid climate responses to gradual insolation forcing, Quaternary Sci. Rev., 19, 347-361, doi:10.1016/S0277-3791(99)00081-5, 2000.

De Paolo, D. J. and Wasserburg, G. J.: Nd isotope variations and netrogenetic models, Geoohvs. Res. Let. Washington 3, 60176040, 1976.

De Vleeschouwer, F., Gérard, L., Goormaghtigh, C., Mattielli, N., Le Roux, G., and Fagel, N.: Atmospheric lead and heavy metal pollution records from a Belgian peat bog spanning the last two millennia: Human impact on a regional to global scale, Sci. Total Environ., 377, 282-295, 2007.

Delmonte, B., Petit, J. R., and Maggi, V.: Glacial to Holocene implications of the new 27,000-year dust record from the EPICA Dome C (East Antarctica) ice core, Clim. Dynam., 18, 647-660, 2002.

Delmonte, B., Basile-Doelsch, I., Petit, J. R., Maggi, V., RevelRolland, M., Michard, A., Jagoutz, E., and Grousset, F.: Com- paring the EPICA and Vostok dust records during the last 220 000 years: stratographical correlation and origin in glacial periods, Earth Sci. Rev., 66, 63-87, 2004.

De Vleeschouwer, F., Luthers, C., Mauquoy, D., Wastiaux, C., Le Roux, G., Moschen, R., Pawlyta, J., Pazdur, A., Sikorski, J., and Piotrowska, N.: Multiproxy paleoenvironmental study in the Misten bog (East Belgium) during the last millennium, Quaternary Int., 268, 44-57, 2012.

Fagel, N., Innocent, C., Stevenson, R., and Hillaire-Marcel, C.: Deep circulation changes in the Labrador Sea since the Last Glacial Maximum: New constraints from Sm-Nd data on sediments, Paleoceanography, 14, 0883-8305, 1999.

Ferket, H., Muchez, P., Schroyen, K., and Sintubin, M.: Metamorphism in the Stavelot-Venn Massif: a study of quartz veins in the basal devonian conglomerates (Lochkovian), Aardkundige Mededelingen, 9, 7-16, 1998.

Gabrielli, P., Wegner, A., Petit, J.R., Delmonte, B., De Deckker, P., Gaspari, V., Fischer, H., Ruth, U., Kriews, M., Boutron, C., Cescon, P., and Barbante, C.: A major glacial-interglacial change in aeolian dust composition inferred from Rare Earth Elements in Antarctic ice, Quaternary Sci. Rev., 29, 265-273, 2010.

Gallet, S., Jahn B., Lanoe, B. V. V, Dia, A., and Rossello, E.: Loess geochemistry and its implications for particle origin and composition of the upper continental crust, Earth Planet. Sci. Lett., 156, 157-172, 1998.

Givelet, N., Le Roux G., Cheburkin, A., Chen, B., Frank, J., Goodsite, M. E., Kempter, H., Krachler, M., Noernberg, T., Rausch, N., Rheinberger, S., Roos-Barraclough, F., Sapkota, A., Scholz, C., and Shotyk, W.: Suggested protocol for collecting, handling and preparing peat cores and peat samples for physical, chemical, mineralogical and isotopic analyses, J. Environ. Monit., 6, 481-492, 2004.

Goudie, A. S.: The global distribution of dust storms, An. Arid Zone, 40, 1-12, 2001.

Goudie, A. S. and Middleton, N. J.: Desert Dust in the Global System, Springer, 2006.

Grimm, E. C.: CONISS: A fortran 77 program for stratigraphically constrained cluster analysis by the method of incremental sum of squares, Comp. Geosci., 13, 13-35, 1987.

Grousset, F. E. and Biscaye, P. E.: Continental aerosols, isotopic fingerprints of sources and atmospheric transport: a review, Chem. Geol., 222, 149-167, 2005.

Grousset, F. E., Ginoux, P., Bory, A., and Biscaye, P. E.: Case study of a Chinese dust plume reaching the French Alps, Geophys. Res. Lett., 30, 1277, doi:10.1029/2002GL016833, 2003.

Handley, H. K., Turner, S., Macpherson, C. G., Gertisser, R., and Davidson, J. P.: Hf-Nd isotope and trace element constraints on subduction inputs at island arcs: Limitations of $\mathrm{Hf}$ anomalies as sediment input indicators, Earth Planet. Sci. Let., 304, 212-223, 2011.

Johnsen, S. J., Dahl-Jensen, D., Gundestrup, N., Steffensen, J. P., Clausen, H. B., Miller, H., Masson-Delmotte, V., Sveinbjörnsdottir, A. E., and White, J.: Oxygen isotope and palaeotemperature records from six Greenland ice-core stations: Camp Century, Dye-3, GRIP, GISP2, Renland and NorthGRI, J. Quaternary Sci., 16, 299-307, 2001.

Kamanov, G. D., Brenner, M., and Tucker, J. L.: Anthropogenic versus natural control on trace element and $\mathrm{Sr}-\mathrm{Nd}-\mathrm{Pb}$ isotiope stratigraphy in peat sediments of southeast Florida (USA), 
1500 AD to present, Geochem. Cosmochim. Acta, 73, 35493567, 2009.

Krachler, M., Mohl, C., Emons, H., and Shotyk, W.: Two thousand years of atmospheric rare earth element (REE) deposition as revealed by an ombrotrophic peat bog profile, Jura Mountains, Switzerland, J. Environ. Monitor., 5, 111-121, 2003.

Kylander, M. E., Muller, J., Wust, R. A. J., Gallagher, K., GarciaSanchez, R., Coles, B. J., and Weiss, D. J.: Rare earth elementand $\mathrm{Pb}$ isotope variations in a 52 kyr peat core from Lynch's Crater (NE Queensland, Australia): proxy development and application to paleoclimate in the Southern Hemisphere, Geochim. Cosmochim. Acta, 71, 942-60, 2007.

Kylander, M. E., Bindler, R., Martínez Cortizas, A., Gallagher, K., Mörth, C. M., and Rauch, S.: A novel geochemical approach to paleorecords of dust deposition and effective humidity: 8500 years of peat accumulation at Store Mosse (the "Great Bog”) Sweden, Quarternary Sci. Rev., 69, 69-82, 2013.

Lambert, F., Bigler, M., Steffensen, J. P., Hutterli, M., and Fischer, H.: Centennial mineral dust variability in high-resolution ice core data from Dome C, Antarctica, Clim. Past, 8, 609-623, doi:10.5194/cp-8-609-2012, 2012.

Lamentowicz, M., Obremska, M., and Mitchell, E. A. D.: Autogenic succession, land-use change, and climatic influences on the Holocene development of a kettle hole mire in Northern Poland. Rev. Palaeobot. Palynol., 151, 21-40, 2008.

Lawson, I. T., Swindles, G. T., Plunkett, G., and Greenberg, D.: The spatial distribution of Holocene cryptotephras in north-west Europe since $7 \mathrm{ka}$ : implications for understanding ash fall events from Icelandic eruptions, Quarternary Sci. Rev., 41, 57-66, 2012.

Lawrence, C. R. and Neff, J. C.: The contemporary physical and chemical flux of Aeolian dust: A synthesis of direct measurements of dust deposition, Chem. Geol., 267, 46-63, 2009.

Le Roux, G., Fagel, N., De Vleeschouwe, F., Krachler, M., Debaille, V., Stille, P., Mattelli, N., Van der Knaap, W. O., Van Leeuwen, J. F. N., and Shotyk, W.: Volcano- and climate-driven changes in atmospheric dust sources and fluxes since the Late Glacial in Central Europe, Geology, 40, 335-338, 2012.

Linnemann, U., Herbosch, A, Liégeois, J.-P., Pin, C, Gärtner, A., and Hofmann, M.: The Cambrian to Devonian odyssey of the Brabant Massif within Avalonia: a review with the new zircon ages, geochemistry, Sm-Nd isotopes, stratigraphy and palaeogeography, Earth Sci. Rev., 112, 126-154, 2012.

Magny, M.: Holocene climatic variability as reflected by midEuropean lake-level fluctuations, and its probable impact on prehistoric human settlements, Quaternary Int., 113, 65-80, 2004.

Martín-Chivelet, J., Muñoz-García, M. B., Edwards, R. L., Turrero, M. J., and Ortega, A. I.: Northern Spain 4000 Year Stalagmite d13C and Temperature Reconstruction, Global Planet. Change, $77,1-12,2011$.

Marx, S. K., Kamber, B. S., and McGowan, H. A.: Provenance of long travelled dust determined with ultra-trace-element composition: a pilot study with samples from New Zealand glaciers, Earth Surf. Process. Landforms, 30, 699-716, 2005.

Marx, S. K., McGowan, H. A., and Kamber, B. S.: Long-range dust transport from eastern Australia: a proxy for Holocene aridity and ENSO-induced climate variability, Earth Planet. Sci. Lett., 282, 167-177, 2009.

Marx, S. K., Kamber, B. S., McGowan, H. A., and Denholm, J.: Holocene dust deposition rates in Australia's Murray-Darling
Basin, record the interplay between aridity, position of the midlatitude westerlies, Quaternary Sci. Rev., 30, 3290-3305, 2011.

Mayewski, P. A., Rohling, E. E., Stager, J. C., Karlen, W., Maasch, K. A., Meeker, L. D., Meyerson, E. A., Gasse, F., van Kreveld, S., Holmgren, K., Lee-Thorp, J., Rosqvist, G. Rack, F., Staubwasser, M., Schneider, R. R., and Steig, E. J.: Holocene climate variability, Quaternary Res., 62, 243-255, 2004.

Meskhidze, N., Chameides, W. L., Nenes, A., and Chen, G.: Iron mobilization in mineral dust: Can anthropogenic $\mathrm{SO}_{2}$ emissions affect ocean productivity?, Geophys. Res. Lett., 30, 2085, doi:10.1029/2003GL018035, 2003.

Moreno, T., Castillo, S., Alastuey, A., Cuevas, E., Herrmann, L., Mounkaila, M., Elvira, J., and Gibbons, W.: Geochemical variations in aeolian mineral particles from the Sahara-Sahel Dust Corridor, Chemosphere, 65, 261-270, 2006.

Müller, B., Höhne, N., and Ellermann, C.: Differentiating (historic) responsibilities for Climate Change, Oxford Institute for Energy Studies (OIES), University of Oxford, Royaume-Un, 2007.

Payne, R. J.: Can testate amoeba-based palaeohydrology be extended to fens?, J. Quaternary Sci., 26, 15-27, 2011.

Payne, R. J. and Mitchell, E. A. D.: How many is enough? Determining optimal count totals for ecological and palaeoecological studies of testate amoebae, J. Paleolimnol., 42, 483-495, 2009.

Piotrowska, N., Blaauw, M., Mauquoy, D., and Chambers, F. M.: Constructing deposition chronologies for peat deposits using radiocarbon dating, Mires and Peat 7, 10, available at: http://www. mires-and-peat.net/, 2011.

Piotrowska, N.: Status report of AMS sample preparation laboratory at GADAM Centre, Gliwice, Poland. Nuclear Instruments and Methods in Physics Research Section B: Beam Interactions with Materials and Atoms, 294, 176-181, 2013.

Reimer, P. J., Baillie, M. G. L., Bard, E., Bayliss, A., Beck, J. W., Blackwell, P. G., Bronk Ramsey, C., Buck, C. E., Burr, G. S., Edwards, R. L., Friedrich, M., Grootes, P.M., Guilderson, T.P., Hajdas, I., Heaton, T. J., Hogg, A. G., Hughen, K. A., Kaiser, K. F., Kromer, B., McCormac, F. G., Manning, S. W., Reimer, R. W., Richards, D. A., Southon, J. R., Talamo, S., Turney, C. S. M., van der Plicht, J., and Weyhenmeyer, C. E.: IntCal09 and Marine09 radiocarbon age calibration curves, $0-50000$ years cal BP, Radiocarbon 5, 1111-1150, 2009.

Roos-Barraclough, F., Martinez-Cortizas, A., GarcIa-Rodeja, E., and Shotyk, W.: A 14500 year record of the accumulation of atmospheric mercury in peat: volcanic signals, anthropogenic influences and a correlation to bromine accumulation, Earth Planet. Sci. Lett., 202, 435-451, 2002.

Sapkota, A.: Mineralogical, chemical, and isotopic ( $\mathrm{Sr}, \mathrm{Pb}$ ) Composition of atmospheric mineral dusts in an ombrotrophic peat bog, Southern South America, PhD Thesis, Ruprecht-KarlsUniversität, Heidelberg, Germany, 2006.

Sapkota, A., Cheburkin, A. K., Bonani, G., and Shotyk, W.: Six millenia of atmospheric dust deposition in southern South America (Isla Navarino, Chile), Holocene, 17, 561-572, 2007.

Shotyk, W.: Peat bog archives of atmospheric metal deposition: geochemical evaluation of peat profiles, natural variations in metal concentrations, and metal enrichment, Environ. Rev., 4, 149183, 1996.

Shotyk, W., Weiss, D., Appleby, P. G., Cheburkin, A. K., Frei, R., Gloor, M., Kramers, J. D., Reese, S., and van der Knaap, W. O.: History of atmospheric lead deposition since 12,370 14C yr BP 
recorded in a peat bog profile, Jura Mountains, Switzerland, Science, 281, 1635-1640, 1998.

Shotyk, W., Weiss, D., Kramers, J. D., Frei, R., Cheburkin, A. K., Gloor, M., and Reese, S.: Geochemistry of the peat bog at Etang de la Gruère, Jura Mountains, Switzerland, and its record of atmospheric $\mathrm{Pb}$ and lithogenic trace metals ( $\mathrm{Sc}, \mathrm{Ti}, \mathrm{Y}, \mathrm{Zr}$, and $\mathrm{REE}$ ) since 12,370 14C yr BP, Geochim. Cosmochim. Acta, 65, 23372360, 2001.

Shotyk, W., Krachler M., Martinez-Cortizas, A., Cheburkin, A. K., and Emons, H.: A peat bog record of natural, pre-anthropogenic enrichments of trace elements in atmospheric aerosols since $1237014 \mathrm{C}$ yr BP, and their variation with Holocene climate change, Earth Planet. Sci. Lett., 199, 21-37, 2002.

Sillasoo, U., Mauquoy, D., Blundell, A., Charman, D., Blaauw, M., Daniell, J. R. G., Toms, P., Newberry, J., Chambers, F. M., and Karofeld, E.: Peat multi-proxy data from Mannikjarve bog as indicators of late Holocene climate changes in Estonia, Boreas, 36, 20-37, 2007.

Sjogren, P.: The development of pasture woodland in the southwest Swiss Jura Mountains over 2000 years, based on three adjacent peat profiles, The Holocene, 16, 210-223, 2006.

Taylor S. R.: The Encyclopedia of Geochemistry and Environmental Sciences, Stroudsburg, Pennsylvania, 1972.

Taylor, S. R. and McLennan, S. M.: The Continental Crust: Its Composition and Evolution, Blackwell, Oxford, 1985.

Thompson, L. G., Mosley-Thompson, E., Davis, M., Lin, P.-N., Henderson, K. A., Cole-Dai, J., Bolzan, J. F., and Liu, K. B.: Late glacial stage and Holocene tropical ice core records from Huascaran, Peru, Science, 269, 46-50, 1995.

Thompson, L. G., Mosley-Thompson, E., Davis, M. E., Henderson, K. A., Brecher, H. H., Zagorodnov, V. S., Mashiotta, T. A., Lin, P.-N., Mikhalenko, V. N., Hardy, D. R., and Beer, J.: Ice core records: evidence of Holocene climate change in tropical Africa, Science, 298, 589-593, 2000.

Thompson, L. G., Mosley-Thompson, E., Davis, M. E., Lin, P. N., Henderson, K., and Mashiotta, T. A.: Tropical glacier and ice core evidence of climate change on annual to millennial timescales, Clim. Change, 59, 137-155, 2003.
Tegen, I., Werner, M., Harrison, S. P., and Kohfeld, K. E.: Relative importance of climate and land use in determining present and future global soil dust emission, Geophys. Res. Lett., 31, L05105, doi:10.1029/2003GL019216, 2004.

Väliranta, M., Korhola, A., Seppä, K. Tuittila, E.-S., SarmajaKorjonen, K., Laine, J., and Alm, J.: High-resolution reconstruction of wetness dynamics in a southern boreal raised bog, Finland, during the late Holocene: a quantitative approach, The Holocene, 17, 1093-1107, 2007;

Wanner, H., Beer, J., Butikofer, J., Crowley, T., Cubasch, U., Fluckiger, J., Goosse, H., Grosjean, M., Joos, F., Kaplan, J. O., Kuttel, M., Muller, S., Pentice, C., Solomina, O., Stocker, T., Tarasov, P., Wagner, M., and Widmann, M.: Mid to late Holocene climate change - an overview, Quaternary Sci. Rev., 27, 1791-1828, 2008.

Wanner, H., Solomina, O., Grosjean, M., Ritz, S. P., and Jetel, M.: Structure and origin of Holocene cold events, Quaternary Sci. Rev., 30, 3109-3123, 2011.

Wardenaar E.: A new hand tool for cutting peat profiles, Revue canadienne de botanique, 65, 1771-1772, 1987.

Wastiaux, C. and Schumacker, R. : Topographie de surface et de subsurface des zones tourbeuses des réserves naturelles domaniales des Hautes-Fagnes. Rapport de synthèse. Convention C60 entre l'Université de Liège et le Ministère de la Région Wallonne (D.G.R.N.E.), rapport inédit: 52 p., 2003.

Ylirukanen, I. and Lehto, S.: The occurrence of rare earth elements in some Finnish mires, Bull. Geol. Soc. Finland, 67, 27-38, 1995.

Zdanowicz, C. M., Zielinski, G. A., Wake, C., Fisher, D. A., and Koerner, R. M.: A Holocene record of atmospheric dust deposition on the Penny Ice Cap, Baffin Island, Canada, Quaternary Res., 53, 62-69, 2000. 